\title{
"ORGANIZATIONAL LEARNING,SOFT SKILLS OR HARD SKILLS: WHICH ARE MORE IMPORTANT TO REINFORCE TEACHERS INNOVATION IN EARLY CHILDHOOD EDUCATION PROGRAMS."
}

\author{
Ahmad $^{1}$, Teguh Setiawan Wibowo ${ }^{2}$, Kisno $^{3}$, Nur Agus Salim ${ }^{4}$, Ahmad Tohir ${ }^{5}$, Azlin Atika Putri ${ }^{6}$, \\ Widayat Mintarsih $^{7}$, M. Sobry ${ }^{8}$, Abdul Mufid ${ }^{9}$ \\ ${ }^{1}$ Universitas Islam Indragiri Riau, Indonesia ${ }^{2}$ STIE Mahardhika Surabaya, Indonesia ${ }^{3}$ Institut Agama Islam Negeri Metro, \\ Indonesia ${ }^{4}$ Universitas Widya Gama Mahakam Samarinda, Indonesia ${ }^{5}$ STKIP Al Islam Tunas Bangsa, Indonesia ${ }^{6}$ Universitas \\ Lancang Kuning, Indonesia ${ }^{7}$ UIN Walisongo Semarang, Indonesia ${ }^{8}$ UIN Mataram, Indonesia ${ }^{9}$ Sekolah Tinggi Agama Islam \\ Khozinatul Ulum Blora, Indonesia \\ CorespondingAuthor :mufid.prof@gmail.com
}

\begin{abstract}
:
The purpose of this study was to measure the influence of hard skills and soft skills on teacher of early childhood education through organizational learning as a mediating variable. This study used quantitative methods. Data were collected by distributing questionnaires to all teachers in early childhood schools. Data were collected by using simple random sampling via electronic to theof early childhood education teacher in Jabodetabek. The number of returned and valid questionnaires was 300 respondents. Data were processed by using SEM with SmartPLS 3.0. The results of the study concluded that hard and soft skills had positive and significant influence on teacher innovation capability, both directly and indirectly through a mediating effect of organizational learning.
\end{abstract}

Keywords:

Hard skills, early childhood education, organizational learning, soft skills, teacher innovation capability

Article Received: 18 October 2020, Revised: 3 November 2020, Accepted: 24 December 2020

\section{INTRODUCTION}

Improving the quality of human resources in this case is that teachers are very urgent and need to be done in a planned, directed and sustainable manner in order to improve their abilities and professionalism. The goal of developing the quality of human resources is to improve the operational performance of office holders in carrying out government tasks, in this case the teacher is tasked with improving the quality (output) of students, educating students, and having noble character as provisions for the next generation. a nation that will assume the life of the state and religion. In addition, the high quality of teacher resources will lead to the birth

of a strong commitment in completing routine tasks according to their respective responsibilities and functions more efficiently, effectively and productively.

Teachers are expected not only to have hard skills or technical and academic expertise in their work, but teachers must also be supported by good soft skills, otherwise it's no wonder that after decades of work, a teacher's achievement has not improved. Very different from those who have good soft skills, their achievements will gradually continue to climb to reach a higher level.The ability of teachers' hard skills is the infrastructure and the soft skills of teachers are superstructures. A building is said to be complete if the infrastructure and superstructure exists. Therefore, the main point in this case is the ability to unify hard skills and soft skills of teachers for the continuity and success of a professional teacher as an educator.Apart from the two intelligences above, a teacher is also expected to have a Spiritual Skill or Spiritual intelligence. Spiritual Skill is a person's ability to face and solve problems that are attached to a broader and richer meaning and value. Spiritual intelligence gives a person the ability and perspective to see positive values in every problem and wisdom to deal with problems based on heart or heart.With the three 
components above (hard skills, soft skills and spiritual skills), it is hoped that they can motivate a teacher to carry out their work and responsibilities. This needs to be addressed because in the future the problems and challenges to be faced will be even more severe and complex. For this reason, it requires reliable employee resources, who have high work motivation in anticipating various problems.

Hard skills are skills that can produce something visible and immediate. The notion of hard skills is often interpreted as determining the size of an individual in terms of technical abilities which can be seen from the evidence they have, such as certificates, awards, etc. This means that hard skills are obtained by someone through educational institutions to obtain the abilities that support them in solving them. Hard skills are often used as a measure of a person's ability or the expertise of the quality of employees owned by agencies in society. Therefore, it is imperative for teachers to have good hard skills with the aim that what is the hope that exists in the community can provide a positive value to the educational institution. This means that educational institutions or schools want to demonstrate that teachers and employees have competence in knowledge and technology and are able to respond to a changing environment.

Soft skills are the ability or emotional intelligence of a person, which is built in two parts, namely intrapersonal and interpersonal competences. Hard skills are professional competences that a person must have, namely the ability of teachers to carry out their work professions. Meanwhile, soft skills are intrapersonal competencies, namely the ability to understand and control oneself.This intrapersonal competence consists of: understanding of success, self-evaluation, selfimage, goal setting, self-motivation. Interpersonal competence is our competence to socialize and interact with others, this competency consists of: emotional control, self-confidence, intensive communication, and human relations. Therefore, this intrapersonal competence is very important for teachers.Soft Skills is an implementation of a person's emotional intelligence which is a requirement of a job. Teachers must have soft skills in two categories, namely the ability of teachers to organize themselves (intrapersonal skills) and the ability of teachers to relate to other people (interpersonal skills) which are included in interpersonal skills, namely communication skills, motivation skills, leadership skills, charismatic, presentation skills , political awareness, exploiting diversity, service orientation, empathy, conflict management and teamwork. Meanwhile, intrapersonal skills consist of character transformation, belief transformation, change management, stress management, time management, creative thinking processes, setting goals and life goals, self-confidence, assessment of traits, self and preferences, emotional awareness, feasibility and proactivity.Soft skills will appear when someone is performing, such as speaking ability that reflects ideas and information, or explaining a topic clearly, easy understanding of unfamiliar topics, being able to interact and work cooperatively in groups. Teachers with good quality softs kills will reflect abilities that exceed their capacity as educators. This ability arises because the person concerned is able to independently move internal processes to continue learning, trying, and finding something that benefits his work or self-development.

An organizational environment that provides excitement at work is an important factor of teacher innovation capability (Bani-Melhem, Zeffane\& Albaity,2018).Honeycutt (2000) explained that knowledge management is a discipline that manages intellectual capital from managed assets. Basically, the concept of knowledge management develops from the fact that in the present and future, the main assets of an organization to be able to compete are intellectual assets rather than physical assets. In general, knowledge management carried out by organizational learning is a way to manage 
knowledge in organizations to create value and increase competitive advantage. Organizational learning as a mediating variable plays a role between hard skills, soft skills, and organizational innovation. In addition, this process has been considered a system where knowledge and skills are input, organizational learning is the main process, and organizational innovation is an important output (Nouri \& Ghorbani, 2017; Chang, Liao \& Wu , 2017). Based on the explanation above, there are hypotheses as follows:

$\mathrm{H}^{1}$ : Hard skill has a direct effect on teacher innovation capability

$\mathrm{H}^{2}$ : Soft skill has a direct effect onteacher innovation capability

$\mathrm{H}^{3}$ : Hard skill has a direct effect on organizational learning

$\mathrm{H}^{4}$ : Soft skill has a direct effect on organizational learning

$\mathrm{H}^{5}$ : Organizational learning has a direct effect on teacher innovation capability

$\mathrm{H}^{6}$ : Hard skill has an indirect effect on teacher innovation capability through a mediating effect of organizational learning

$\mathrm{H}^{7}$ : Soft skills has an indirect effect on teacher innovation capability through a mediating effect of organizational learning

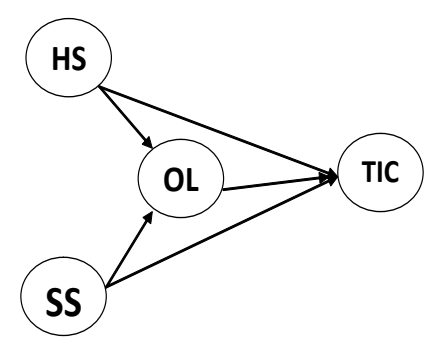

Figure1. Research Model

\section{METHODS}

This study used quantitative methods. Data were collected by distributing questionnaires to all teachers in early childhood schools. This study used 6 items to measure hard skills by Hendarman \& Cantner (2017). This study used 4 items to measure soft skills by Hendarman \& Cantner (2017). Organizational learning by Jimenez-Jimenez and Sanz-Valle (2011) was measured by using 5 items. Teacher innovation capability by Lee \& Choi (2003) was measured by using 5 items. This study uses close-ended questionnaires except for questions/statements about the identity of respondents in the form of semi-open questionnaires. Each closed question/statement item has five answer options, namely: strongly agree (SS) with a score of 5 , agree (S) with a score of 4 , fairly disagree (KS) with a score of 3 , disagree (TS) with a score of 2, and strongly disagree (STS) with a score of 1 . Data were processed by using the PLS method with SmartPLS version 3.0 software. The population in this study wereearly childhood schoolsteachers in Jakarta, the questionnaire was distributed electronically with a simple random sampling technique. The number of returned questionnaires was 300.This method alse conducted by Cahyono (2020); Nico (2019); Fahmi (2020); Vizano (2020) ; Pramono (2020) ; Dezky (2020); Asbari (2020); Bernarto (2020); Sartika (2020); Suheny (2020); Supriadi (2020) ;Kadiyono (2020);Zena (2020); Cahyono (2020); Kartika (2020) ;Asbari (2020) ;Wibowo ( 2020); Nugroho (2020) and Purwanto (2020) 
Table 1.Respondents Description

\begin{tabular}{llc}
\hline & Criteria & Total \\
\hline Age & $<30$ years old & 108 \\
& $30-40$ years old & 92 \\
& $>40$ years old & 100 \\
\hline Work Experience & $<5$ years & 106 \\
& $5-10$ years & 100 \\
& $>10$ years & 94 \\
\hline Educational level & $<\mathrm{S} 1$ & 255 \\
& $\geq \mathrm{S} 1$ & 45 \\
\hline
\end{tabular}

\section{RESULTSAND DISCUSSION}

Measurement model tests include convergent validity, discriminant validity, and composite reliability tests.For most references, a loading factor of 0.5 or more is considered to have validation that is strong enough to explain latent constructs (Chin, 1998; Hair et al, 2010; Ghozali, 2014). In this study, the minimum acceptable loading factor is 0.5 , with the condition that the AVE value for each construct is> 0.5 (Ghozali, 2014). Based on the PLS model estimation results in the figure above, all indicators had a loading factor value above 0.5 so that the model met the convergent validity requirements. Apart from looking at the loading factor value of each indicator, convergent validity was also assessed from the AVE value of each construct. The AVE value for each construct was already above 0.5. So the convergent validity of this study met the requirements. This test method also conducted by Cahyono (2020); Nico (2019); Fahmi (2020); Vizano (2020) ; Pramono (2020) ; Dezky (2020); Asbari (2020); Bernarto (2020); Sartika (2020); Suheny (2020); Supriadi (2020) ;Kadiyono (2020);Zena (2020); Cahyono (2020); Kartika (2020) ;Asbari (2020) ;Wibowo ( 2020); Nugroho (2020) and Purwanto (2020)

The value of items loadings, Cronbach's alpha, composite reliability and AVE of each construct can be seen in Table 2: 


\begin{tabular}{|c|c|c|c|c|c|}
\hline Varables & Items & Loadings & $\begin{array}{c}\text { Cronbach's } \\
\text { Alpha }\end{array}$ & $\begin{array}{l}\text { Composite } \\
\text { Reliability }\end{array}$ & AVE \\
\hline Hard Skills & HS1 & 0.766 & 0.875 & 0.832 & 0.586 \\
\hline \multirow[t]{3}{*}{ (HS) } & HS2 & 0.678 & & & \\
\hline & HS3 & 0.765 & & & \\
\hline & HS4 & 0.794 & & & \\
\hline Soft Skills & SS1 & 0.746 & 0.756 & 0.953 & 0.775 \\
\hline \multirow[t]{3}{*}{$(S S)$} & SS2 & 0.675 & & & \\
\hline & SS3 & 0.876 & & & \\
\hline & SS4 & 0.654 & & & \\
\hline $\begin{array}{l}\text { Organizational } \\
\text { Learning }\end{array}$ & OL1 & 0.543 & 0.987 & 0.874 & 0.675 \\
\hline \multirow[t]{3}{*}{ (OL) } & OL2 & 0.653 & & & \\
\hline & OL3 & 0.653 & & & \\
\hline & OL4 & 0.765 & & & \\
\hline Innovation Capability & TIC1 & 0.676 & 0.812 & 0.832 & 0.575 \\
\hline \multirow[t]{3}{*}{ (TIC) } & TIC 2 & 0.654 & & & \\
\hline & TIC 3 & 0.765 & & & \\
\hline & TIC 4 & 0.789 & & & \\
\hline
\end{tabular}

Table2. Items Loadings, Cronbach's Alpha, Composite Reliability, and Average Variance Extracted (AVE)

A discriminant validity test is carried out to ensure that each concept of each latent variable is different from the other latent variables. The model has good discriminant validity if the AVE squared value of each exogenous construct (the value on the diagonal) exceeds the correlation between the construct and other constructs (values below the diagonal) (Ghozali, 2014). The results of the discriminant validity test by using AVE squared values or by looking at the FornellLarcker Criterion Value can be seen in Table 3:

\begin{tabular}{ccccc}
\hline Variables & HS & OL & SS & TIC \\
\hline HS & $\mathbf{0 . 8 7 5}$ & & & \\
OL & 0.652 & $\mathbf{0 . 7 7 5}$ & & \\
SS & 0.678 & 0.675 & $\mathbf{0 . 8 8 6}$ & \\
TIC & 0.636 & 0.746 & 0.564 & $\mathbf{0 . 7 2 5}$ \\
\hline
\end{tabular}

\section{Table3.Discriminant Validity}

The results of the discriminant validity test in Table 3 showed that all constructs had the AVE square root value above the correlation value with other latent constructs (through the FornellLarcker criteria) so that it can be concluded that the model met the discriminant validity.Construct reliability can be assessed from the value of Cronbach's alpha and composite reliability of each construct. The recommended composite reliability and Cronbach's alpha values are more than 0.7. (Ghozali, 2014). The reliability test results in table 2 above showed that all constructs had composite 
reliability and Cronbach's alpha values of greater than 0.7 (> 0.7). So it can be concluded that all constructs met the required reliability. . This test method also conducted by Cahyono (2020); Nico (2019); Fahmi (2020); Vizano (2020) ; Pramono (2020) ; Dezky (2020); Asbari (2020); Bernarto (2020); Sartika (2020); Suheny (2020); Supriadi (2020) ;Kadiyono (2020);Zena (2020); Cahyono (2020); Kartika (2020) ;Asbari (2020) ;Wibowo ( 2020); Nugroho (2020) and Purwanto (2020)

\section{Hypothesis testing}

Hypothesis testing in PLS is also called the inner model test. This test includes a test of the significance of direct and indirect effects and measurement of the influence of exogenous variables on endogenous variables. To know the influence of tacit knowledge and hard skills sharing on organizational learning and teacher innovation capability, a direct influence test is needed. The direct effect test was performed by using the t-statistic test in a partial least squared (PLS) analysis model with SmartPLS 3.0 software. By using the bootstrapping technique, $\mathrm{R}$ Square values and significance test values were obtained as follows:

Table4. R Square Value

\begin{tabular}{ccc}
\hline & R Square & R Square Adjusted \\
\hline TIC & 0.667 & 0.653 \\
OL & 0.578 & 0.525
\end{tabular}

Based on Table 4 above, the value of $R$ Square of OL was 0.578 which means that organizational learning (OL) was explained by hard skills (HS) and soft skills (SS) variables by $57.8 \%$, while the remaining $42.3 \%$ was explained by other variables not discussed in this study. Meanwhile, the value of $\mathrm{R}$ Square of teacher innovation capability (TIC) was 0.667 which means that the teacher innovation capability variable was explained by hard skills, soft skills and organizational learning by $66.7 \%$, while the remaining $39.8 \%$ was explained by other variables not discussed in this study. This test method also conducted by Cahyono (2020); Nico (2019); Fahmi (2020); Vizano (2020) ; Pramono (2020) ; Dezky (2020); Asbari (2020); Bernarto (2020); Sartika (2020); Suheny (2020); Supriadi (2020) ;Kadiyono (2020);Zena (2020); Cahyono (2020); Kartika (2020) ;Asbari (2020) ;Wibowo ( 2020); Nugroho (2020) and Purwanto (2020)

Table 5 shows $\mathrm{T}$ Statistics and P-Values which show the influence between variables

Table5. Hypotheses Testing

\begin{tabular}{clccccc}
\hline Hypotheses & Relationship & Beta & SE & T Statistics & V-Values & Decision \\
\hline H1 & HS -> TIC & 0.284 & 0.043 & 6.652 & 0.000 & Supported \\
H2 & SS -> TIC & 0.126 & 0.040 & 3.198 & 0.001 & Supported \\
H3 & HS -> OL & 0.371 & 0.037 & 9.957 & 0.000 & Supported \\
H4 & SS -> OL & 0.478 & 0.035 & 13.822 & 0.000 & Supported \\
H5 & OL -> TIC & 0.511 & 0.047 & 10.955 & 0.000 & Supported \\
H6 & HS -> OL ->TIC & 0.190 & 0.029 & 6.440 & 0.000 & Supported \\
H7 & SS -> OL ->TIC & 0.244 & 0.026 & 9.327 & 0.000 & Supported \\
\hline
\end{tabular}

\section{$\mathbf{H}^{1}$ : Hard skill has a direct effect on teacher innovation capability}

Based on statistical calculations with PLS in Table 5 above, it can be concluded that Hard skill has a direct effect on teacher innovation capability. This is evidenced by the t-statistics value of 6.652 greater than 1.96 and the p-value of 0.000 less than 0.050. That is, the hypothesis is accepted. These findings are in line with and in accordance with the results of previous studies by Kadiyono (2020);Zena (2020); Cahyono (2020) which states that Hard skill has a direct effect on teacher innovation capability.

\section{H$^{2}$ : Soft skill has a direct effect on teacher innovation capability}

Based on statistical calculations with PLS in Table 5 above, it can be concluded that Soft skill has a direct effect onteacher innovation capability. This is evidenced by the t-statistics value of 3.198 greater than 1.96 and the p-value of 0.000 less than 0.050. That is, the hypothesis is accepted. These findings are in line with and in accordance with the results of previous studies by Wibowo ( 2020); Nugroho (2020) and Purwanto (2020)which states that Soft skill has a direct effect onteacher innovation capability 
$H^{3}$ : Hard skill has a direct effect on organizational learning

Based on statistical calculations with PLS in Table 5 above, it can be concluded that Hard skill has a direct effect on organizational learning. This is evidenced by the t-statistics value of 9.957 greater than 1.96 and the p-value of 0.000 less than 0.050 . That is, the hypothesis is accepted. These findings are in line with and in accordance with the results of previous studies by Kadiyono (2020);Zena (2020); Cahyono (2020); Kartika (2020) ;Asbari (2020) ;Wibowo ( 2020); Nugroho (2020) and Purwanto (2020); Cahyono (2020); Kartika (2020); Fahmi (2020); Sartika (2020) and Vizano (2020)which states that Hard skill has a direct effect on organizational learning

$H^{4}$ : Soft skill has a direct effect on organizational learning

Based on statistical calculations with PLS in Table 5 above, it can be concluded that Soft skill has a direct effect on organizational learning. This is evidenced by the t-statistics value of 13.822greater than 1.96 and the p-value of 0.000 less than 0.050 . That is, the hypothesis is accepted. These findings are in line with and in accordance with the results of previous studies by Kadiyono (2020);Zena (2020); Cahyono (2020); Kartika (2020) ;Asbari (2020) ;Wibowo ( 2020); Nugroho (2020) and Purwanto (2020); Cahyono (2020); Kartika (2020); Fahmi (2020); Sartika (2020) and Vizano (2020) which states that Soft skill has a direct effect on organizational learning.

$H^{5}$ : Organizational learning has a direct effect on teacher innovation capability

Based on statistical calculations with PLS in Table 5 above, it can be concluded that Organizational learning has a direct effect on teacher innovation capability. This is evidenced by the t-statistics value of 10.955 greater than 1.96 and the $p$-value of 0.000 less than 0.050 . That is, the hypothesis is accepted. These findings are in line with and in accordance with the results of previous studies by Kadiyono (2020);Zena (2020; Nugroho (2020) and Purwanto (2020); Cahyono (2020); Kartika (2020); Fahmi (2020); Sartika (2020) and Vizano
(2020) which states that Organizational learning has a direct effect on teacher innovation capability

\section{$\mathbf{H}^{6}$ : Hard skill has an indirect effect on teacher innovation capability through a mediating effect of organizational learning}

Based on statistical calculations with PLS in Table 5 above, it can be concluded that Hard skill has an indirect effect on teacher innovation capability through a mediating effect of organizational learning. This is evidenced by the t-statistics value of 6.440 greater than 1.96 and the p-value of 0.000 less than 0.050 . That is, the hypothesis is accepted. These findings are in line with and in accordance with the results of previous studies by Kadiyono (2020);Zena (2020; Nugroho (2020) and Purwanto (2020); Cahyono (2020); Kartika (2020); Fahmi (2020); Sartika (2020) and Vizano (2020) which states that Hard skill has an indirect effect on teacher innovation capability through a mediating effect of organizational learning.

\section{$H^{7}$ : Soft skills has an indirect effect on teacher innovation capability through a mediating effect of organizational learning}

Based on statistical calculations with PLS in Table 5 above, it can be concluded that Hard skill has an indirect effect on teacher innovation capability through a mediating effect of organizational learning. This is evidenced by the t-statistics value of 9.327 greater than 1.96 and the p-value of 0.000 less than 0.050 . That is, the hypothesis is accepted. These findings are in line with and in accordance with the results of previous studies by Kadiyono (2020);Zena (2020; Nugroho (2020) and Purwanto (2020); Cahyono (2020); Kartika (2020); Fahmi (2020); Sartika (2020) and Vizano (2020) which states that Hard skill has an indirect effect on teacher innovation capability through a mediating effect of organizational learning.

\section{DISCUSSION}

Based on the results of the study, hard skills sharing had positive and significant influence on teacher innovation capability, both direct effects 
and mediating effects of organizational learning. This shows that the better hard skills possessed by teachers, the teacher innovation capability of individuals in a school will also increase. This is in line with a study on business organizations by Perez-Luno et al (2018), Terhorst et al (2018), Boadu et al (2018), Che et al (2019). Soft skills had a significant and positive influence on teacher innovation capability, both direct effects and the mediating effect of organizational learning. This shows that the better soft skills possessed by teachers, the teacher innovation capability will also increase. In addition, it can be concluded that organizational learning was a mediator between teacher soft skills and teacher innovation capability.Eni F. \& Rahayu W (2014) The Influence of Hard Skills, Soft Skills and Spiritual Skills on Lecturer Work Productivity in Malang. Using statistical data analysis techniques. Data analysis to determine the effect of independent variables on related variables by using multiple linear regression analysis which was processed through the SPSS computer program. The results of testing the first hypothesis show that simultaneously both hard skills (X1), soft skills (X2) or spiritual skills (X3) have an effect on lecturer work productivity (Y).. Razid.Z., Tewel.B., \& Kojo.C. (1 2018) The Influence of Hard Skill and Soft Skill on Employee Performance of Perum Damri Manado. From the results of the regression test on the first hypothesis that hard skills and soft skills have a positive effect on employee performance, with a significant value less than 0.05 , it means that there is a positive and significant effect. effect on employee performance, with the t-count value of each variable, namely hard skills (X1) 6,200 and soft skills (X2) 2,014. Akhmad J. \& Wahyuni (2017) The Effect of Soft Skills and Hard Skills on Employee Performance at the Education Office of South Sulawesi Province. From the results of the regression test on the first hypothesis that hard skills have a positive and significant effect on employee performance with a significant value less than 0.05 , it means that there is a positive and significant effect on employee performance. The results of the regression test on the hypothesis can also be concluded that assault skills have a positive and significant effect on employee performance, with a significant value less than 0.05 using the SPSS version 21 program.Hard skills describe explicit behaviors and skills. Hard skills are skills that can produce something that is visible and direct. Hard skills can be assessed from technical tests or practical tests. The elements of hard skills can be seen from the intelligence quotient thinking that has indicators namely, counting, analyzing, designing, comprehensive knowledge, modeling, and critical thinking. Hard skills are related to mastery of science, technology, and technical skills. Teachers must have skills in opening lessons, managing classes, designing group discussions, organizing classrooms, and writing well (Muqowim, 2012). Hard skills are relatively easy to measure. Widoyoko divided hard skills into two, namely academic and vocational skills. Academic skills are the ability to master various concepts in the field of study, such as skills to define, calculate, explain, describe, classify, identify, predict, analyze, compare, differentiate, and draw conclusions from various concepts, data, and facts related to a subject(Widoyoko, 2009).Good organizational learning will be more resilient to crises (Starbuck, 2017). Dimensions such as desire, discipline, decision making, and alignment are presented as important elements of organizational learning (Wetzel \& Tint, 2019; Urban \& Gaffurini, 2018). Organizational learning is an important performance indicator to evaluate overall organizational performance (Qi \& Chau, 2018) that can build the necessary knowledge resources and maintain school growth and continuity. The ability to access knowledge is a distinguishing factor between one school and another. The success of the school strategy is very significant related to the solid knowledge base that is owned by every individual in a school.

Several studies concluded that soft skills had a greater influence on innovation than hard skills 
(Ibrahim, Boerhannoeddin \& Bakare, 2017; Albandea \& Giret, 2018; Viviers, Fouche \& Reitsma, 2016; Escrig-Tena et al, 2018). However, this study showed that hard skills had a greater influence on teacher innovation capability. Based on the results of the study, organizational learning had positive and significant influence on teacher innovation capability. Organizational learning was mediating the influence of hard skills and soft skills on teacher innovation capability. This is in line with a study by Martinez-Costa (2018). This study also concluded that a school can manage past experiences to be combined with the current hard skills and soft skills of teachers. In essence, organizational learning could provide positive conditions in the process of knowledge creation in the 4.0 era.

Hard skills are very important to be developed, because a person's ability to do a job properly and correctly depends on how hard the skills he has. There was no way a person could make a useful tool if he did not know how it was made, its purpose, and its use. or it is impossible for someone to fix something if he does not know what he is fixing. Even before applying for a job, higher education graduates (students) should pay attention to the job they will accept with their abilities. It's a good thing to compare abilities with the work to be done. For that students need to prepare themselves by developing hard skills as a basis for applying for jobs and balanced with soft skills as a basis for doing work. Because almost all companies today require an appropriate combination of hard skills and soft skills, regardless of the position of the employee. For employee recruitment for companies, the hard skill approach alone has now been abandoned. It's useless if hard skills are good, but soft skills are bad. This can be seen in the job advertisements of various companies which also require soft skills, such as team work, communication skills, and interpersonal relationships, in their job requirements. Companies tend to choose candidates who have better personalities even though their hard skills are lower. The reason is that providing skills training is much easier than character building This shows that hard skills are an important factor in work, but a person's success at work is usually more determined by good soft skills. Today's work world requires skilled resources, as a student. Hard skills are required to have high hard skill skills, hard skills are the expertise of how the final grades of students / academic grades (GPA) of these students are a requirement to fulfill the administration in applying for a company, besides having to have a high GPA in this era of intense competition as well. We are required to have soft skills, namely someone's skills in dealing with other people (interpersonal skills), skills in managing himself (intrapersonal skills). Both hard skills and soft skills are a prerequisite for the success of a scholar in life after completing his education. aim. As explained above, hard skills are emphasized on cognitive aspects and special skills according to certain scientific disciplines, while soft skills are personal behaviors and interpersonal skills needed to develop and optimize the performance of a human.

Soft skills are personal and interpersonal behaviors that develop and maximize performance such as building communication teams, decision making, and initiatives. Soft skills do not include technical skills such as computer assembling skills, but soft skills include the understanding of nontechnical skills, which can complement the academic abilities and abilities that everyone should have, regardless of the profession they are engaged in. Professions such as doctors, teachers, police, accountants, traders, farmers, nurses and fishermen must have soft skills. Teachers must have strong soft skills because soft skills are skills in dealing with other people (interpersonal skills) and skills in managing themselves (intrapersonal skills) that are able to develop to work optimally. Based on this definition, soft skills are personal qualities that are inward and outward. If we have these various qualities then we will become great, advanced and successful human beings. Interpersonal skills are important abilities to have 
which include the ability to communicate, warm relationships, build constructive relationships, use diplomacy and techniques to dissolve tense situations and use styles that can strengthen friendship. Thomas and Diane (1990) distinguish between impersonal communication and interpersonal communication. In interpersonal communication, each person understands each other, but there is no emotional involvement, while interpersonal communication has a much higher quality of closeness than impersonal. Interpersonal skills are the ability to build relationships with other people. Apart from soft skills, the abilities that a person must have are hard skills. Hard skills can be assessed from a technical test or practical test. We can see the element of hard skills from intelligence quotation thinking with indicators in the form of the ability to count, design, analyze, broad knowledge and insights, make models and be critical. Meanwhile, soft skills refer to indicators of creativity, sensitivity and intuition that lead to personal qualities behind one's behavior. Soft skills that must be possessed by a teacher and nurse profession include being honest, responsible, working hard, having commitment, being willing to continue to learn, being able to work together, respecting others, being able to adapt, and being humble. However, when it comes to hard skills, the two professions require different qualities. A teacher must have the skills to open lessons, design lessons, manage classes, organize discussion groups, and write well. These skills do not need to be possessed by nurses because a nurse only requires mastery of technical skills, for example how to inject patients. After we know the difference between hard skills and soft skills, pay attention to the greatness of people who have high soft skills. In a study conducted by Philip (2002), almost all leaders in the world have good interpersonal skills. One proof of this is their ability to maintain longstanding relationships with colleagues, friends and partners. People who do well in their fields on average also have good interpersonal skills. They are able to respect others, keep their agreement, keep their feelings, and are able to put themselves.

\section{CONCLUSIONS}

Hard skill has a direct effect on teacher innovation capability, Soft skill has a direct effect onteacher innovation capability,Hard skill has a direct effect on organizational learning, Soft skill has a direct effect on organizational learning,Organizational learning has a direct effect on teacher innovation capability,Hard skill has an indirect effect on teacher innovation capability through a mediating effect of organizational learning, Soft skills has an indirect effect on teacher innovation capability through a mediating effect of organizational learningTeacher training in each section of the school is a necessity with a level of intensity and context that is adjusted to the key performance indicators of each teacher.. This study had several limitations. First, this study analyzed the influence of hard skills and soft skills on teacher innovation capability of teachers, both direct and indirect through organizational learning variables. Because there will be several other variables that influence teacher innovation capability, the researchers strongly recommend to find, explore and analyze them. Secondly, this study was conducted in a school environment and may not be generalized to other industries. Therefore it is highly recommended that further studies can be performed on this topic in other industries.In increasing teacher work motivation, there needs to be efforts that encourage teachers to be initiative, creative, and innovative. With the hope that the principal can provide opportunities for every teacher to further improve their profession so that learning outcomes can be of higher quality. 2 . Hard Skills, Soft Skills and Spiritual Skills must be continuously improved and possessed by the teacher so that their work motivation will improve, so that the enthusiasm for carrying out their duties and obligations will improve and increase in the hope of producing maximum student output. Teachers must be willing to open up themselves on the insight and development of science and technology to increase work 
motivation, work quality and work results in accordance with the vision and mission that have been built together. Giving good attention to the principal will motivate teachers to be more effective in carrying out tasks, especially those related to learning and other school programs

\section{REFERENCES}

[1] Al-Kurdi, O., El-Haddadeh, R., \& Eldabi, T. (2018).Knowledge sharing in higher education institutions: a systematic review. Journal of Enterprise Information Management, $\quad 31(2), \quad 226-$ 246.doi:10.1108/jeim-09-2017-0129

[2] Asbari, M., Santoso, P., and Purwanto, A. (2019).Pengaruh kepemimpinan dan budaya sekolah terhadap perilaku kerja inovatif pada industri 4.0.JIM UPB (Jurnal Ilmiah Manajemen Universitas Putera Batam), 8(1), 7-15. doi:10.33884/jimupb.v8i1.1562

[3] Asher, D., \& Popper, M. (2019).Soft skills as a multilayer phenomenon: the "onion" model. The Learning Organization.doi:10.1108/tlo-06-2018-0105

[4] Assyne N. (2019) Hard Competencies Satisfaction Levels for Software Engineers: A Unified Framework. In: Hyrynsalmi S., Suoranta M., Nguyen-Duc A., Tyrväinen P., Abrahamsson P. (eds) Software Business. ICSOB 2019. Lecture Notes in Business Information Processing, vol 370. Springer, Cham.https://doi.org/10.1007/978-3-03033742-1A27

[5] Attia, A. and Salama, I. (2018), "Knowledge management capability and supply chain management practices in the Saudi food industry", Business Process Management Journal, Vol. 24 No. 2, pp. 459477.https://doi.org/10.1108/BPMJ-01-2017$\underline{0001}$

[6] Aulawi, H. (2018). Improving Teacher innovation capability Trough Creativity and Knowledge Sharing Behavior. IOP Conference Series: Materials Science and
Engineering, 434 ,

012242. doi:10.1088/1757-899x/434/1/012242

[7] Azim, S., Gale, A., Lawlor-Wright, T., Kirkham, R., Khan, A., \& Alam, M. (2010).The importance of soft skills in complex projects.International Journal of Managing Projects in Business, 3(3), 387401.doi:10.1108/17538371011056048

[8] Baldé, M., Ferreira, A. and Maynard, T. (2018), "SECI driven creativity: the role of team trust and intrinsic motivation", Journal of Knowledge Management, Vol. 22 No. 8, pp.

1688-1711.

https://doi.org/10.1108/JKM-06-2017-0241

[9] Bani-Melhem, S., Zeffane, R. and Albaity, M. (2018), "Determinants of employees' innovative behavior", International Journal of Contemporary Hospitality Management, Vol. 30 No. 3, pp. 16011620.https://doi.org/10.1108/IJCHM-022017-0079

[10] Bashir, M. and Farooq, R. (2019), "The synergetic effect of knowledge management and business model innovation on firm competence: A systematic review", International Journal of Innovation Science, Vol. 11 No. 3, pp. 362-387. https://doi.org/10.1108/IJIS-10-2018-0103

[11] Boadu, F., Xie, Y., Du, Y.-F., \& DwomoFokuo, E. (2018).MNEs Subsidiary Training and Development and Firm Innovative Performance: The Moderating Effects of Tacit and Hard skills Received from Headquarters. Sustainability, 10(11), 4208.doi:10.3390/su10114208

[12] Borges, R., Bernardi, M. and Petrin, R. (2019), "Cross-country findings on soft skills sharing: evidence from the Brazilian and Indonesian IT workers", Journal of Knowledge Management, Vol. 23 No. 4, pp. 742-762. https://doi.org/10.1108/JKM-04$\underline{2018-0234}$

[13] Borrego, G., Morán, A. L., Palacio, R. R., Vizcaíno, A., \& García, F. O. (2019).Towards a reduction in architectural 
knowledge vaporization during agile global software development.Information and Software Technology. doi:10.1016/j.infsof.2019.04.008

[14] Boske, C. and Osanloo, A. (2015), "Conclusion - Preparing all School Community Leaders to Live their Work", Living the Work: Promoting Social Justice and Equity Work in Schools around the World (Advances in Educational Administration, Vol. 23), Emerald Group Publishing Limited, pp. 405-426. https://doi.org/10.1108/S1479$\underline{366020140000023032}$

[15] Cairó Battistutti, O. \& Bork, D. Cogn Process (2017) 18: 461. https://doi.org/10.1007/s10339-017-0825-6

[16] Cantwell, J. and Zaman, S. (2018), "Connecting local and global technological knowledge sourcing", Competitiveness Review, Vol. 28 No. 3, pp. 277294.https://doi.org/10.1108/CR-08-20170044

[17] Castela, B., Ferreira, F., Ferreira, J. and Marques, C. (2018), "Assessing the teacher innovation capability of small- and mediumsized enterprises using a non-parametric and integrative approach", Management Decision, Vol. 56 No. 6, pp. 1365-1383. https://doi.org/10.1108/MD-02-2017-0156

[18] Chang, C. and Lin, T. (2015), "The role of organizational culture in the knowledge management process", Journal of Knowledge Management, Vol. 19 No. 3, pp. 433-455.https://doi.org/10.1108/JKM-082014-0353

[19] Chang, W.-J., Liao, S.-H., \& Wu, T.-T. (2017). Relationships among organizational culture, knowledge sharing, and innovation capability: a case of the automobile industry in Taiwan. Knowledge Management Research \& Practice, 15(3), 471490.doi:10.1057/s41275-016-0042-6

[20] Chatterjee, A., Pereira, A. and Sarkar, B. (2018), "Learning transfer system inventory
(LTSI) and knowledge creation in organizations", The Learning Organization, Vol. 25 No. 5, pp. 305319.https://doi.org/10.1108/TLO-06-2016$\underline{0039}$

[21] Che, T., Wu, Z., Wang, Y. and Yang, R. (2019), "Impacts of knowledge sourcing on employee innovation: the moderating effect of information transparency", Journal of Knowledge Management, Vol. 23 No. 2, pp. 221-239. https://doi.org/10.1108/JKM-112017-0554

[22] Che, T., Wu, Z., Wang, Y., \& Yang, R. (2018).Impacts of knowledge sourcing on employee innovation: the moderating effect of information transparency. Journal of Knowledge Management.doi:10.1108/jkm11-2017-0554

[23] Chen, H., Baptista Nunes, M., Ragsdell, G., \&An, X. (2018). Extrinsic and intrinsic motivation for experience grounded soft skills sharing in Chinese software organisations. Journal of Knowledge Management, 22(2), 478498.doi:10.1108/jkm-03-2017-0101

[24] Chin, WW. (1998). The Partial Least Squares Approach to Structural Equation Modeling. Modern Methods for Business Research, In: G. A. Marcoulides, Ed., Lawrence Erlbaum Associates Publisher, New Jersey, pp. 295-336.

[25] Cifariello, P., Ferragina, P., \& Ponza, M. (2019).Wiser: A semantic approach for expert finding in academia based on entity linking. Information Systems, 82, 1-16. doi:10.1016/j.is.2018.12.003

[26] Culot, G., Orzes, G., \& Sartor, M. (2019).Integration and scale in the context of Industry 4.0: the evolving shapes of manufacturing value chains. IEEE Engineering Management Review, 1-1. doi:10.1109/emr.2019.2900652

[27] Darwish, T. K., Zeng, J., Rezaei Zadeh, M., \& Haak-Saheem, W. (2018).Organizational learning of Absorptive Capacity and 
Innovation: Does Leadership Matter? European Management Review. doi:10.1111/emre. 12320

[28] Deranek, K., McLeod, A., \& Schmidt, E. (2017).ERP Simulation Effects on Knowledge and Attitudes of Experienced Users. Journal of Computer Information Systems, $1-11$. doi:10.1080/08874417.2017.1373610

[29] Durana, Kral, Stehel, Lazaroiu, \& Sroka. (2019). Quality Culture of Manufacturing Enterprises: A Possible Way to Adaptation to Industry 4.0.Social Sciences, 8(4), 124.doi:10.3390/socsci8040124

[30] Fan, C.S., Wei, X., and Zhang, J. (2017). Soft Skills, Hard Skills, and The Black/White Wage Gap. Wiley Online Library. 55(2):1032-1052. Doi: https://doi.org/10.1111/ecin.12406

[31] Ferraris, A., Santoro, G. and Scuotto, V. (2018), "Dual relational embeddedness and knowledge transfer in European multinational corporations and subsidiaries", Journal of Knowledge Management, Vol. ahead-of-print No. ahead-ofprint.https://doi.org/10.1108/JKM-09-20170407

[32] Ferreira, J., Mueller, J. and Papa, A. (2018), "Strategic knowledge management: theory, practice and future challenges", Journal of Knowledge Management, Vol. ahead-ofprint No. ahead-of-print. https://doi.org/10.1108/JKM-07-2018-0461

[33] Gale, A. J., Duffey, M. A., Park-Gates, S., \& Peek, P. F. (2017).Soft Skills versus Hard Skills: Practitioners' Perspectives on Interior Design Interns. Journal of Interior Design, 42(4), 45-63. doi:10.1111/joid.12105

[34] Ganguly, A., Talukdar, A. and Chatterjee, D. (2019), "Evaluating the role of social capital, soft skills sharing, knowledge quality and reciprocity in determining teacher innovation capability of an organization", Journal of Knowledge Management, Vol. 23
No. 6, pp. 1105-

1135.https://doi.org/10.1108/JKM-03-20180190

[35] Ghozali, I. Structural Equation Modeling, Metode Alternatif dengan Partial Least Square (PLS), Edisi 4. Semarang: Badan Penerbit Universitas Diponegoro. 2014.

[36] Gunasekaran, A., Subramanian, N., \& Ngai, E. (2018). Quality Management in the 21st Century Enterprises: Research pathway towards Industry 4.0. International Journal of

Production

Economics.doi:10.1016/j.ijpe.2018.09.005

[37] Guo, Y., Jasovska, P., Rammal, H. and Rose, E. (2018), "Global mobility of professionals and the transfer of soft skills in multinational service firms", Journal of Knowledge Management, Vol. ahead-ofprint No. ahead-ofprint.https://doi.org/10.1108/JKM-09-2017$\underline{0399}$

[38] Haamann, T., \& Basten, D. (2018). The role of information technology in bridging the knowing-doing gap: an exploratory case study on knowledge application. Journal of Knowledge Management.doi:10.1108/jkm01-2018-0030

[39] Hair, J. F., Black. W. C., Babin. B. J.; and Anderson. R. E. (2010), Multivariate Data Analysis, 7th ed. New Jersey: Pearson Prentice Hall.

[40] Hamada, T. (2019).Determinants of Decision-Makers' Attitudes toward Industry 4.0 Adaptation.Social Sciences, 8(5), 140.doi: $10.3390 /$ socsci8050140

[41] Hartley, J. (2018), "Ten propositions about public leadership", International Journal of Public Leadership, Vol. 14 No. 4, pp. 202217.https://doi.org/10.1108/IJPL-09-2018$\underline{0048}$

[42] Haseeb, M., Hussain, H. I., Ślusarczyk, B., \& Jermsittiparsert, K. (2019).Industry 4.0: A Solution towards Technology Challenges of Sustainable Business Performance.Social 
Sciences,

$8(5)$

154.doi:10.3390/socsci8050154

[43] Hodgins, M. and Dadich, A. (2017), "Positive emotion in knowledge creation", Journal of Health Organization and Management, Vol. 31 No. 2, pp. 162174.https://doi.org/10.1108/JHOM-06-20160108

[44] Holford, W.D. (2018). The future of human creative knowledge work within the digital economy.Futures.

doi:10.1016/j.futures.2018.10.002

[45] Holste, J. S., \& Fields, D. (2010).Trust and soft skills sharing and use. Journal of Knowledge Management, 14(1), 128140.doi:10.1108/13673271011015615

[46] Honeycutt, Jerry. (2000). Knowledge Management Strategies: Strategi Manajemen Pengetahuan. Jakarta : PT. Alex Media Komputindo.

[47] Hong, J. (1999). Structuring for organizational learning.The Learning Organization, Vol. 6 No. 4, pp. 173186.https://doi.org/10.1108/0969647991028 $\underline{0631}$

[48] Huang, F., Gardner, S. and Moayer, S. (2016), "Towards a framework for strategic knowledge management practice: Integrating soft and hard systems for competitive advantage", VINE Journal of Information and Knowledge Management Systems, Vol. 46 No. 4, pp. 492-507. https://doi.org/10.1108/VJIKMS-08-2015$\underline{0049}$

[49] Huesig, S. and Endres, H. (2019), "Exploring the digital innovation process: The role of functionality for the adoption of innovation management software by innovation managers", European Journal of Innovation Management, Vol. 22 No. 2, pp. 302-314. https://doi.org/10.1108/EJIM-022018-0051

[50] Hussain, S. T., Lei, S., Akram, T., Haider, M. J., Hussain, S. H., \& Ali, M. (2018). Kurt Lewin's change model: A critical review of the role of leadership and employee involvement in organizational change. Journal of Innovation \&Knowledge, 3(3), 123-127. doi:10.1016/j.jik.2016.07.002

[51] Imran, M., Ilyas, M., Aslam, U. and Fatima, T. (2018), "Knowledge processes and firm performance: the mediating effect of employee creativity", Journal of Organizational Change Management, Vol. 31 No. 3, pp. 512-531. https://doi.org/10.1108/JOCM-10-2016$\underline{0202}$

[52] Jakhar, S. K., Mangla, S. K., Luthra, S., \& Kusi-Sarpong, S. (2018). When stakeholder pressure drives the circular economy.Management

Decision.doi:10.1108/md-09-2018-0990

[53] Jaleel, S. and Verghis, A.M. (2015).Knowledge Creation in Constructivist Learning.Universal Journal of Educational Research 3(1): 8-12. doi: 10.13189/ujer.2015.030102.

[54] Jiménez-Jiménez, D., \& Sanz-Valle, R. (2011).Innovation, organizational learning, and performance. Journal of Business Research, 64(4), 408-417. doi:10.1016/j.jbusres.2010.09.010

[55] Jou, M. Lin, Y. and Wu, D. (2016) Effect of a blended learning environment on student critical thinking and knowledge transformation, Interactive Learning Environments, 24:6, 1131-1147, DOI: $\underline{10.1080 / 10494820.2014 .961485}$

[56] Kasim, A., Ekinci, Y., Altinay, L. and Hussain, K.(2018)Impact of market orientation, organizational learning and market conditions on small and medium-size hospitality enterprises,Journal of Hospitality Marketing \& Management,27:7,855875,DOI: $10.1080 / 19368623.2018 .1438955$

[57] Kawamura, K. (2016), "Kristine Marin Kawamura, PhD interviews Ikujiro Nonaka, PhD", Cross Cultural \& Strategic Management, Vol. 23 No. 4, pp. 613-632. 
https://doi.org/10.1108/CCSM-06-2014-

$\underline{0056}$

[58] Kenayathulla, H., Ahmad, N. and Idris, A. (2019), "Gaps between competence and importance of employability skills: evidence from Malaysia", Higher Education Evaluation and Development, Vol. 13 No. 2, pp. 97-112. https://doi.org/10.1108/HEED08-2019-0039

[59] Khoshsorour, A., Gilaninia, S. 2018. Kuwait Chapter of the Arabian.Journal of Business and Management Review; Kuwait City 7(3): 1-4. doi: 10.12816/0048627

[60] Kim, N. and Shim, C. (2018). Social capital, knowledge sharing and innovation of smalland medium-sized enterprises in a tourism cluster. International Journal of Contemporary Hospitality Management, Vol. 30 No. 6, pp. 2417-2437. https://doi.org/10.1108/IJCHM-07-20160392

[61] Klaeijsen, A., Vermeulen, M., \& Martens, R. (2017).Teachers' Innovative Behaviour: The Importance of Basic Psychological Need Satisfaction, Intrinsic Motivation, and Occupational Self-Efficacy. Scandinavian Journal of Educational Research, 62(5), 769-782.

doi:10.1080/00313831.2017.1306803

[62] Laker, D. R., \& Powell, J. L. (2011).The differences between hard and soft skills and their relative impact on training transfer. Human Resource Development Quarterly, 22(1), 111-122. doi:10.1002/hrdq.20063

[63] Lecat, A., Beausaert, S. \& Raemdonck, I. (2018). On the Relation Between Teachers' (In)formal Learning and Innovative Working Behavior: the Mediating Role of Employability. Vocations and Learning11, 529-554. doi:10.1007/s12186-018-9199-X

[64] Lee, J.-C., Shiue, Y.-C., \& Chen, C.-Y. (2016). Examining the impacts of organizational culture and top management support of knowledge sharing on the success of software process improvement.
Computers in Human Behavior, 54, 462474. doi:10.1016/j.chb.2015.08.030

[65] Lee, Peter. (2019). Soft skills and University-Industry Technology Transfer.Research Handbook on Intellectual Property and Technology Transfer (2019, Forthcoming); UC Davis Legal Studies Research Paper Forthcoming.doi: http://dx.doi.org/10.2139/ssrn.3417933

[66] Li, M., Liu, H. and Zhou, J. (2018), "GSECI model-based knowledge creation for CoPS innovation: the role of grey knowledge", Journal of Knowledge Management, Vol. 22 No. 4, pp. 887-911. https://doi.org/10.1108/JKM-10-2016-0458

[67] Li, Song, Wang, \& Li. (2019).Intellectual Capital, Knowledge Sharing, and Innovation Performance: Evidence from the Chinese Construction Industry. Sustainability, 11(9), 2713.doi:10.3390/su11092713

[68] Liebowitz, J. and Chen, Y. 2001. Developing knowledge-sharing proficiencies.Knowledge Management Review 3(6): 12-15. https://www.researchgate.net/publication/ 285908349ADeveloping AknowledgesharingAproficienciesABuildingAaAsupport iveA cultureAforAknowledge-sharing

[69] Lievre, P. and Tang, J. (2015), "SECI and inter-organizational and intercultural knowledge transfer: a case-study of controversies around a project of cooperation between France and China in the health sector", Journal of Knowledge Management, Vol. 19 No. 5, pp. 1069-1086. https://doi.org/10.1108/JKM-02-2015-0054

[70] Lin, C.-P. (2006). To Share or Not to Share: Modeling Soft skills Sharing, Its Mediators and Antecedents. Journal of Business Ethics, 70(4), 411-428.doi:10.1007/s10551-0069119-0

[71] Lin, H., Lee, Y. (2017). A Study of The Influence of Organizational learning on Employees' Innovative Behavior and Work Engagement by A Cross-Level Examination. 
Eurasia Journal of Mathematics, Science and Technology Education, 13(7), 34633478.https://doi.org/10.12973/eurasia.2017.0 $0738 \mathrm{a}$

[72] Lombardi, R. (2019). Knowledge transfer and organizational performance and business process: past, present and future researches. Business Process Management Journal, 25(1), 2-9.doi:10.1108/bpmj-022019-368

[73] Lund, H. B., \& Karlsen, A. (2019).The importance of vocational education institutions in manufacturing regions: adding content to a broad definition of regional innovation systems. Industry and Innovation, 1-20. doi:10.1080/13662716.2019.1616534

[74] Ma, Q., Mayfield, M. and Mayfield, J. (2018), "Keep them on-board! How organizations can develop employee embeddedness to increase employee retention", Development and Learning in Organizations, Vol. 32 No. 4, pp. 5-9. https://doi.org/10.1108/DLO-11-2017-0094

[75] Malik, A. (2019). Creating competitive advantage through source basic capital strategic humanity in the industrial age 4.0.International Research Journal of Advanced Engineering and Science 4(1): 209-215. www.irjaes.com/pdf/V4N1Y18IRJAES/IRJAES-V4N1P195Y19.pdf

[76] Manaf, H. A., Armstrong, S. J., Lawton, A., \& Harvey, W. S. (2017).Managerial Soft skills, Individual Performance, and the Moderating Role of Employee Personality. International Journal of Public Administration, $1-13$. doi:10.1080/01900692.2017.1386676

[77] Martínez-Costa, M., Jiménez-Jiménez, D., \& Dine Rabeh, H. A. (2018).The effect of organisational learning on interorganisational collaborations in innovation: an empirical study in SMEs. Knowledge Management Research \&
Practice, $1-14$. doi:10.1080/14778238.2018.1538601

[78] Mohajan, Haradhan (2016): Sharing of Soft skills in Organizations: A Review. Published in: American Journal of Computer Science and Engineering, Vol. 3, No. 2 (1 July 2016): pp. 6-19. https://mpra.ub.unimuenchen.de/id/eprint/82958

[79] Moustaghfir, K. and Schiuma, G. (2013), "Knowledge, learning, and innovation: research and perspectives", Journal of Knowledge Management, Vol. 17 No. 4, pp. 495-510. https://doi.org/10.1108/JKM-042013-0141

[80] Muhammad, A., Ariyani, E.D., Sadikin, S., Sujana, D. (2019).Factor Analysis of the Companies Demands to the Polytechnic Graduates in Indonesia. Advanced Science Letters, Volume 25, Number 1, January 2019, pp. 117121(5)DOI:https://doi.org/10.1166/asl.2019. 13199

[81] Muñoz, C.A., Mosey, S. and Binks, M.(2015)The tacit mystery: reconciling different approaches to soft skills.Knowledge Management Research \& Practice, 13:3,289298,DOI: $10.1057 / \mathrm{kmrp} .2013 .50$

[82] Muqowim (2012).Pengembangan Soft Skills Guru. Yogyakarta: Pedagogia

[83] Muscio, A., \& Ciffolilli, A. (2019).What drives the capacity to integrate Industry 4.0 technologies? Evidence from European $R \& D$ projects. Economics of Innovation and New Technology, 1-15. doi:10.1080/10438599.2019.1597413

[84] Muthuveloo, R., Shanmugam, N., \& Teoh, A. P. (2017). The impact of soft skills management on organizational performance: Evidence from Malaysia. Asia Pacific Management Review, 22(4), 192-201. doi:10.1016/j.apmrv.2017.07.010

[85] Naqshbandi, M., Tabche, I. and Choudhary, N. (2019), Managing open innovation: The roles of empowering leadership and employee involvement climate, Management 
Decision, Vol. 57 No. 3, pp. 703-723. https://doi.org/10.1108/MD-07-2017-0660

[86] Nonaka I., Hirose Nishihara A. (2018) Introduction to the Concepts and Frameworks of Knowledge-Creating Theory. In: Hirose Nishihara A., Matsunaga M., Nonaka I., Yokomichi K. (eds) Knowledge Creation in Community Development. Palgrave Macmillan, Cham. https://doi.org/10.1007/978-3-319-574813A1

[87] Nonaka I., Toyama R. (2015) The Knowledge-creating Theory Revisited: Knowledge Creation as a Synthesizing Process. In: Edwards J.S. (eds) The Essentials of Knowledge Management. OR Essentials Series. Palgrave Macmillan, London.

https://doi.org/10.1057/9781137552105A4

[88] Norwich, B., Koutsouris, G., Fujita, T., Ralph, T., Adlam, A. and Milton, F. (2016), "Exploring knowledge bridging and translation in lesson study using an interprofessional team", International Journal for Lesson and Learning Studies, Vol. 5 No. 3, pp. 180-195.https://doi.org/10.1108/IJLLS$\underline{\text { 02-2016-0006 }}$

[89] Nouri, B.A., \& Ghorbani, R. (2017). The Effect of Knowledge Management on Organizational Innovation with the Mediating Role of Organizational Learning (Case Study : Agricultural Bank in Iran). Journal of Applied Economics and Business Research JAEBR, 7(3): 194-211. https://www.semanticscholar.org/paper/TheEffect-of-Knowledge-Management-onInnovation-of-NouriGhorbani/fb9eb1df37e4a47c9b3ac2bbf0bbc 4f4907b80a2

[90] Nugroho, M. (2018), "The effects of collaborative cultures and knowledge sharing on organizational learning", Journal of Organizational Change Management, Vol. 31 No. 5, pp. 1138-
1152.https://doi.org/10.1108/JOCM-10$\underline{2017-0385}$

[91] Okuyama, R. (2017), "Importance of soft skills in incremental innovation: Implications from drug discovery cases", Journal of Strategy and Management, Vol. 10 No. 1, pp. 118-130. https://doi.org/10.1108/JSMA-02-2016-0016 [92] Parida, V., Sjödin, D., \& Reim, W. (2019).Reviewing Literature on Digitalization, Business Model Innovation, and Sustainable Industry: Past Achievements and Future Promises. Sustainability, 11(2), 391.doi:10.3390/su11020391

[93] Pérez-Fuillerat, N., Solano-Ruiz, M. C., \& Amezcua, M. (2018).Conocimiento tácito: características en la práctica enfermera. Gaceta Sanitaria. doi:10.1016/j.gaceta.2017.11.002

[94] Pérez-Luño, A., Alegre, J., \& Valle-Cabrera, R. (2018).The role of soft skills in connecting knowledge exchange and combination with innovation. Technology Analysis \& Strategic Management, 1-13. doi:10.1080/09537325.2018.1492712

[95] Pérez-Luño, A., Alegre, J., \& Valle-Cabrera, R. (2018).The role of soft skills in connecting knowledge exchange and combination with innovation. Technology Analysis \& Strategic Management, 1-13. doi:10.1080/09537325.2018.1492712

[96] Polanyi, M. (1966).The Tacit dimension. New York: Doubleday \& Co.

[97] Prasarnphanich, P., Janz, B. and Patel, J. (2016), "Towards a better understanding of system analysts' soft skills: A mixed method approach", Information Technology \& People, Vol. 29 No. 1, pp. 69-98. https://doi.org/10.1108/ITP-06-2014-0123

[98] Qi, C. and Chau, P.Y.K.(2018)Will enterprise social networking systems promote knowledge management and organizational learning? An empirical 
study,Journal of Organizational Computing and Electronic Commerce,28:1,31-57,DOI: $\underline{10.1080 / 10919392.2018 .1407081}$

[99] Rainsbury, E., Hodges, D., Burchell, N. \& Lay, M. C. (2002). Ranking workplace competencies: Student and graduate perceptions. Asia-Pacific Journal of Cooperative Education, 3(2), 8-18. https://hdl.handle.net/10289/3219

[100]Razmerita L., Phillips-Wren G., Jain L.C. (2016) Advances in Knowledge Management: An Overview. In: Razmerita L., Phillips-Wren G., Jain L. (eds) Innovations in Knowledge Management. Intelligent Systems Reference Library, vol 95. Springer, Berlin, Heidelberg.https://doi.org/10.1007/978-3$\underline{662-47827-1 \mathrm{~A} 1}$

[101]Rothberg, H. and Erickson, G. (2017), "Big data systems: knowledge transfer or intelligence insights?",Journal of Knowledge Management, Vol. 21 No. 1, pp. 92-112. https://doi.org/10.1108/JKM-07-2015-0300

[102]Ruiz-Torres, A., Cardoza, G., Kuula, M., Oliver, Y. and Rosa-Polanco, H. (2018), "Logistic services in the Caribbean region: An analysis of collaboration, innovation capabilities and process improvement", Academia Revista Latinoamericana de Administración, Vol. 31 No. 3, pp. 534-552. https://doi.org/10.1108/ARLA-03-20170078

[103]Rumanti, A. A., Samadhi, T. M. A. A., Wiratmadja, I. I., \& Sunaryo, I. (2018).A systematic literature review on knowledge sharing for innovation: Empirical study approach. 5th International Conference on Industrial Engineering and Applications (ICIEA). doi:10.1109/iea.2018.8387153

[104]Rumanti, A. A., Wiratmadja, I. I., Sunaryo, I., Ajidarma, P., \& Ari Samadhi, T. M. A. (2019).Firm Teacher innovation capability through Knowledge Sharing at Indonesian Small and Medium Industries: Impact of Tacit and Hard skills Perspective. 2019
IEEE 6th International Conference on Industrial Engineering and Applications (ICIEA). doi:10.1109/iea.2019.8714947

[105]Samsir, S. (2018), The effect of leadership orientation on innovation and its relationship with competitive advantages of small and medium enterprises in Indonesia, International Journal of Law and Management, Vol. 60 No. 2, pp. 530-542. https://doi.org/10.1108/IJLMA-01-2017$\underline{0005}$

[106]Santoro, G., Vrontis, D., Thrassou, A., \& Dezi, L. (2017).The Internet of Things: Building a knowledge management system for open innovation and knowledge management capacity. Technological Forecasting and Social Change. doi:10.1016/j.techfore.2017.02.034

[107]Sasaki, Y. (2017), "A note on systems intelligence in knowledge management", The Learning Organization, Vol. 24 No. 4, pp. 236-244.https://doi.org/10.1108/TLO-092016-0062

[108] Schuckert, M., Kim, T., Paek, S. and Lee, G. (2018), "Motivate to innovate: How authentic and transformational leaders influence employees' psychological capital and service innovation behavior", International Journal of Contemporary Hospitality Management, Vol. 30 No. 2, pp. 776-796. https://doi.org/10.1108/IJCHM-052016-0282

[109]Serna M., E., Bachiller S., O., \& Serna A., A. (2017).Knowledge meaning and management in requirements engineering. International Journal of Information Management, $\quad 37(3), \quad$ 155-161. doi:10.1016/j.ijinfomgt.2017.01.005

[110]Sousa, M. J., \& Rocha, Á. (2019).Strategic Knowledge Management in the Digital Age. Journal of Business Research, 94, 223-226. doi:10.1016/j.jbusres.2018.10.016

[111]Spraggon, M. and Bodolica, V. (2017), "Collective soft skills generation through play: Integrating socially distributed 
cognition and transactive memory systems", Management Decision, Vol. 55 No. 1, pp. 119-135. https://doi.org/10.1108/MD-052015-0173

[112] Stachová, K., Papula, J., Stacho, Z., \& Kohnová, L. (2019).External Partnerships in Employee Education and Development as the Key to Facing Industry 4.0 Challenges.Sustainability, $\quad$ 11(2), 345.doi:10.3390/su11020345

[113]Stanica, S. and Peydro, J. (2016), "How does the employee cross-training lean tool affect the knowledge transfer in product development processes?",VINE Journal of Information and Knowledge Management Systems, Vol. 46 No. 3, pp. 371-385. https://doi.org/10.1108/VJIKMS-11-20150061

[114] Starbuck, W. (2017), "Organizational learning and unlearning", The Learning Organization, Vol. 24 No. 1, pp. 3038.https://doi.org/10.1108/TLO-11-2016$\underline{0073}$

[115] Stewart, C., Schiavon, L.M. and Bellotto, M.L. (2017) Knowledge, nutrition and coaching pedagogy: a perspective from female Brazilian Olympic gymnasts, Sport, Education and Society, 22(4): 511-527, DOI: $10.1080 / 13573322.2015 .1046428$

[116]Swierczek, A. (2019), "Manufacturer structural embeddedness and the network rent: the intervening role of relational embeddedness in the triadic supply chains", Supply Chain Management, Vol. 24 No. 3, pp. 334-354. https://doi.org/10.1108/SCM06-2018-0232

[117]Tang, V., Yanine, F. and Valenzuela, L. (2016), "Data, information, knowledge and intelligence: The mega-nano hypothesis and its implications in innovation", International Journal of Innovation Science, Vol. 8 No. 3, pp. 199-216. https://doi.org/10.1108/IJIS07-2016-0022

[118]Terhorst, A., Lusher, D., Bolton, D., Elsum, I., \& Wang, P. (2018).Soft skills Sharing in
Open Innovation Projects. Project Management Journal, 49(4), 519.doi:10.1177/8756972818781628

[119]Torres, O. J. J., \& Liang, D. (2016).Knowledge Sharing and the Teacher innovation capability of Chinese Firms: The Role of Guanxi. 2016 International Conference on Industrial Engineering, Management Science and Application (ICIMSA).

doi:10.1109/icimsa.2016.7504015

[120]Tsai, F. and Hsu, I. (2019), "The effects of social capital on knowledge heterogeneity", Management Decision, Vol. 57 No. 5, pp. 1237-1253.https://doi.org/10.1108/MD-122016-0909

[121] Tsotsotso, K., Montshiwa, E., Tirivanhu, P., Fish, T., Sibiya, S., Mlangeni, T., Moloi, M. and Mahlangu, N. (2017), "Determinants of skills demand in a state- intervening labour market: The case of South African transport sector", Higher Education, Skills and WorkBased Learning, Vol. 7 No. 4, pp. 408-422. https://doi.org/10.1108/HESWBL-08-2017$\underline{0050}$

[122]Urban, B. and Gaffurini, E. (2018), "Social enterprises and organizational learning in South Africa", Journal of Entrepreneurship in Emerging Economies, Vol. 10 No. 1, pp. 117-133.https://doi.org/10.1108/JEEE-02$\underline{2017-0010}$

[123]Vijande M.L.S., Sánchez J.Á.L. (2017) The Effects of Organizational learning on Innovation and Performance in Kibs: An Empirical Examination. In: Campbell C.L. (eds) The Customer is NOT Always Right? Marketing Orientationsin a Dynamic Business World. Developments in Marketing Science: Proceedings of the Academy of Marketing Science. Springer, Cham.https://doi.org/10.1007/978-3-319$\underline{\text { 50008-9A227 }}$

[124]Villaluz, V. and Hechanova, M. (2019), "Ownership and leadership in building an innovation culture", Leadership \& 
Organization Development Journal, Vol. 40 No. 2, pp. 138150.https://doi.org/10.1108/LODJ-05-2018$\underline{0184}$

[125]Wang, C., Chen, M. and Chang, C. (2019), "The double-edged effect of knowledge search on innovation generations", European Journal of Innovation Management, Vol. ahead-of-print No. ahead-ofprint.https://doi.org/10.1108/EJIM-04-2018$\underline{0072}$

[126]Wang, J., \& Liu, L. (2019).Study on the mechanism of customers' participation in knowledge sharing. Expert Systems, e12367. doi:10.1111/exsy.12367

[127]Wang, X., Arnett, D. and Hou, L. (2016), "Using external knowledge to improve organizational innovativeness: understanding the knowledge leveraging process", Journal of Business \& Industrial Marketing, Vol. 31 No. 2, pp. 164-173. https://doi.org/10.1108/JBIM-04-2014-0064

[128]Wang, Z., \& Wang, N. (2012).Knowledge sharing, innovation and firm performance. Expert Systems with Applications, 39(10), 8899-8908. doi:10.1016/j.eswa.2012.02.017

[129]Wetzel R., Tint B. (2019) Using Applied Improvisation for Organizational learning in the Red Cross Red Crescent Climate Centre. In: Antonacopoulou E., Taylor S. (eds) Sensuous Learning for Practical Judgment in Professional Practice. Palgrave Studies in Business, Arts and Humanities. Palgrave Macmillan, Cham. https://doi.org/10.1007/978-3-319-99049-

\section{$\underline{1 \mathrm{~A} 3}$}

[130]Widmann, A. and Mulder, R. (2018), "Team learning behaviours and innovative work behaviour in work teams", European Journal of Innovation Management, Vol. 21 No. 3, pp. 501520.https://doi.org/10.1108/EJIM-12-2017$\underline{0194}$

[131]Widoyoko, E.P. (2009). Evaluasi Program Pembelajaran Panduan Praktis bagi
Pendidik dan Calon Pendidik (Yogyakarta: Pustaka

[132]Wójcik, M., Jeziorska-Biel, P., \& Czapiewski, K. (2019).Between words: A generational discussion about farming knowledge sources. Journal of Rural Studies, $\quad 67$, 130-141. doi:10.1016/j.jrurstud.2019.02.024

[133]Xu, M., David, J. M., \& Kim, S. H. (2018).The Fourth Industrial Revolution: Opportunities and Challenges. International Journal of Financial Research, 9(2), 90. doi:10.5430/ijfr.v9n2p90

[134] Yang, Z., Nguyen, V. and Le, P. (2018), Knowledge sharing serves as a mediator between collaborative culture and teacher innovation capability: an empirical research, Journal of Business \& Industrial Marketing, Vol. 33 No. 7, pp. 958-969. https://doi.org/10.1108/JBIM-10-2017-0245

[135]Zambon, I., Cecchini, M., Egidi, G., Saporito, M. G., \& Colantoni, A. (2019).Revolution 4.0: Industry vs. Agriculture in a Future Development for SMEs. Processes, 7(1), 36.doi:10.3390/pr7010036

[136]Zebal, M., Ferdous, A., \& Chambers, C. (2019).An integrated model of marketing knowledge - a soft skills perspective.Journal of Research in Marketing and Entrepreneurship.doi:10.1108/jrme-032018-0018

[137]Zhang, C., Xiao, H., Gursoy, D. and Rao, Y.(2015).Soft skills spillover and sustainability in destination development.Journal of Sustainable Tourism.23(7):1029-1048,DOI: $\underline{10.1080 / 09669582.2015 .1032299}$

[138]Zhu, Q., Krikke, H. and Caniëls, M. (2018), Supply chain integration: value creation through managing inter-organizational learning.International Journal of Operations \& Production Management. 38(1): 211-229. https://doi.org/10.1108/IJOPM-06-2015$\underline{0372}$ 
[139]Zouaghi, F., Sánchez, M., \& Martínez, M. G. (2018).Did the global financial crisis impact firms' innovation performance? The role of internal and external knowledge capabilities in high and low tech industries.Technological Forecasting and Social Change.132: 92-104. doi:10.1016/j.techfore.2018.01.011

[140]Basri, ., Wibowo, . T. S., Abdillah, . A., Kharis, . A., Jaenudin, ., Purwanto, . A., Mufid, . A., Maharani, . S., Badi ati, . A. Q., Fahlevi, . M. \& Sumartiningsih, . S. (2020) Democratic, Authocratic, Bureaucratic and Charismatic Leadership Style: Which Influence School Teachers Performance in Education 4.0 Era?. Systematic Reviews in $\begin{array}{lll}\text { Pharmacy, } & 11 & \text { (9), 277-286. }\end{array}$ doi:10.31838/srp.2020.9.45

[141]Supriadi, O., Musthan, . Z., Saodah, ., Nurjehan, . R., Haryanti, . Y. D., Marwal, . M. R., Purwanto, . A., Mufid, . A., Yulianto, . R. A., Farhan, . M., Fitri, . A. A., Fahlevi, . M. \& Sumartiningsih, . S. (2020) Did Transformational, Transactional Leadership Style and Organizational Learning Influence Innovation Capabilities of School Teachers during Covid-19 Pandemic?. Systematic Reviews in Pharmacy, 11 (9), 299-311. doi:10.31838/srp.2020.9.47

[142] Kadiyono, A. L., Sulistiobudi, . R. A., Haris, . I., Wahab, . M. K. A., Ramdani, . I., Purwanto, . A., Mufid, . A., Muqtada, . M. R., Gufron, . M., Nuryansah, . M., Ficayuma, . L. A., Fahlevi, . M. \& Sumartiningsih, . S. (2020) Develop Leadership Style Model for Indonesian Teachers Performance in Education 4.0 Era. Systematic Reviews in Pharmacy, 11 (9), 363-373.doi:10.31838/srp.2020.9.52

[143]Eman Singgih, Joni Iskandar, Francisca Sestri Goestjahjanti, Mochammad Fahlevi, Multi Nadeak, Khaerul Fahmi, Ridwan
Anwar, Masduki Asbari, Agus Purwanto, (2020), The Role of Job Satisfaction in the Relationship between Transformational Leadership, Knowledge Management, Work Environment and Performance, Solid State Technology, 63 (2s ), 293 - 314

[144]Bahdin Nur Tanjunga, Yurni Rahmanb, Budiyantoc, Badawid, Aep Tata Suryanae, Warni Tune Sumarf, Abdul Mufidg, Agus Purwantoh, Wartoi (2020) The Influence of Transformational Leadership, Job Satisfaction and Organizational Citizenship Behavior on the Performance of Islamic School Teachers. Systematic Reviews in $\begin{array}{lll}\text { Pharmacy, } & 11 & \text { (7), 539-546. }\end{array}$ doi:10.31838/srp.2020.7.78

[145] Abidina, Z., Heddyb, ., Astutic, . Y. G. A., Adhad, . S., Asrorie, . K., Subrotof, . D. E., Zaharag, . V. M., Kahpih, . H. S., Purwantoi, . A., Julyantoj, . O. \& Azizik, . E. (2020) Effect of Transformational and Transactional Leadership Toward Iso 22000:2018 Food Safety Certified Company Performance. Systematic Reviews in Pharmacy, $11 \quad$ (7), 529-538. doi:10.31838/srp.2020.7.77

[146] Yunita Noor Azizaha, Muhammad Khairul Rijalb, Rumainurc, Umi Nuriyatur Rohmahd, Syatria Adymas Pranajayae, Zulaecha Ngiuf, Abdul Mufidg, Agus Purwantoh, Dahlia Haliah Ma`ui (2020) Transformational or Transactional Leadership Style: Which Affects Work Satisfaction and Performance of Islamic University Lecturers During COVID-19 Pandemic?. Systematic Reviews in $\begin{array}{llll}\text { Pharmacy, } & 11 & \text { (7), 577-588. }\end{array}$ doi:10.31838/srp.2020.7.82

[147]Teguh Setiawan Wibowoa, Alfi Qonita Badiatib, Arna Asna Annisac, Mohd Khaidir Abdul Wahabd, M. Rifa Jamaludine, 
Muhamad Rozikanf, Abdul Mufidg, Khaerul

Fahmih, Agus Purwantoi, Akhmad Muhainij (2020) Effect of Hard Skills, Soft Skills, Organizational Learning and Innovation Capability on Islamic University Lecturers' Performance. Systematic Reviews in $\begin{array}{llll}\text { Pharmacy, } & 11 & \text { (7), 556-569. }\end{array}$ doi:10.31838/srp.2020.7.80

[148]Roojil Fadillaha, Miftahus Sururb, Elfriantoc, Ahmad Khoirur Roziqind, Achmad Suhailie, Rina Asih Handayanif, Abdul Mufidg, Agus Purwantoh, Muhajiri, Khaerul Fahmij (2020) THE INFLUENCE OF LEADERSHIP STYLE ON INNOVATION CAPABILITIES OF ISLAMIC SCHOOL TEACHERS IN ORGANIZATIONAL LEARNING PERSPECTIVE DURING COVID-19 PANDEMIC. Systematic Reviews in Pharmacy, $11 \quad$ (7), 589-599. doi:10.31838/srp.2020.7.83

[149]Agus Purwanto, Mochammad Fahlevi, Suesthi Maharani, Fauzi Muharomd, Suryanto, Wahyu Setyaningsih, A. Faidi, Al Azhar, Rudy Pramono, Innocentius Bernarto (2020) Indonesian DOCTORAL Students ARTICLE Publication Barriers in International High Impact JournalS: A Mixed METHODS RESEARCH. Systematic Reviews in Pharmacy, 11 (7), 547-555. doi:10.31838/srp.2020.7.79

[150]Fatonia, Nurce Arifiatib, Etty Nurkhayatic, Ela Nurdiawatid, Fidziahe, Giantoro Pamungkasf, Suhroji Adhag, Irawanh, Agus Purwantoi, Octoberry Julyantoj, Enji Azizik (2020) University Students Online Learning System During Covid-19 Pandemic: Advantages, Constraints and Solutions. Systematic Reviews in Pharmacy, 11 (7), 570-576. doi:10.31838/srp.2020.7.81

[151]Cahyono, Y., Jihadi, . M., Arifin, . Z.,
Purnamasari, . W., Musnaini, ., Wijoyo, . H., Fitriaty, ., Putra, . R. S., Putri, . R. A., Muliansyah, . D., Suryani, . P. \& Purwanto, . A. (2020) Do Servant Leadership Influence Market Performance? Evidence from Indonesian Pharmacy Industries. Systematic Reviews in Pharmacy, 11 (9), 439-451. doi:10.31838/srp.2020.9.62

[152]Kartika, H., Norita, . D., Triana, . N. E., Roswandi, . I., Rahim, . A., Naro, . A., Izzati, . T., Munita, . A. A., Junaedi, . D., Suprihatiningsih, . W., Purwanto, . A. \& Bakti, . C. S. (2020) Six Sigma Benefit for Indonesian Pharmaceutical Industries Performance: A Quantitative Methods Approach. Systematic Reviews in

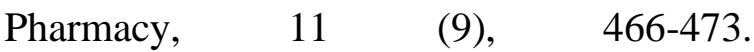
doi:10.31838/srp.2020.9.66

[153]Fahmi, K., Kurniawan, . T., Cahyono, . Y., Sena, . A., Suhadarliyah, ., Suryani, . P., Sugianto, . A., Amelia, . D., Musnaini, ., Amin, . S., Hasbullah, . H., Jihadi, . M., Wijoyo, . H. \& Purwanto, . A. (2020) Did Servant, Digital and Green Leadership Influence Market Performance? Evidence from Indonesian Pharmaceutical Industry. Systematic Reviews in Pharmacy, 11 (9), 642-653. doi:10.31838/srp.2020.9.95

[154], Sartika, . N. S., Subroto, . D. E., Mauladaniyati, . R., Rosdianwinata, . E., Rifai, . R., Sujana, . A., Abidin, . Z., Priadi, . M. D., Setiawati, . E., Yanti, . D. \& Purwanto, . A. (2020) Effect of Pedagogic, Professional Competency, and Work Motivation Toward Indonesian Primary School Teachers Performance. Systematic Reviews in Pharmacy, 11 (9), 617-626. doi:10.31838/srp.2020.9.91

[155]Achmadi, H., Antonio, . F., Pramono, . R., Bernarto, . I. \& Purwanto, .A. (2020) Identification of The Positive and Negative 
Emotions that Appeared among High School Students When Selecting University at Jakarta and Surrounding Area. Systematic Reviews in Pharmacy, 11 (9), 759-766. doi:10.31838/srp.2020.9.107

[156] Vizano, N. A., Utami, . W., Johanes, . S., Herawati, . A., Aima, . H., Sutawijaya, . A. H., Purwanto, . A., Supono, . J., Rahayu, . P., Setiyani, . A., Widayati, . C. C. \& Elmi, .F. (2020) Effect of Career, Organizational Commitment on Turnover Intention through Mediation of Organizational Culture: Evidence from Indonesian Companies. Systematic Reviews in Pharmacy, 11 (9), 931-937. doi:10.31838/srp.2020.9.136

[157]Sena, A., Cahyono, . Y. \& Purwanto, . A. (2020) The Influence of Organizational Culture, Job Satisfaction, and Professional Commitment on Innovative Behavior of Flight Instructors at the Civil Flight School in Indonesia. Systematic Reviews in

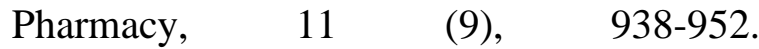
doi:10.31838/srp.2020.9.137

[158]Nugroho, B. S., Widdah, . M. E., Hakim, . L., Nashirudin, . M., Nurlaeli, . A., Purnomo, . J. H., Aziz, . M., Adinugraha, . H. H., Sartika, . M., Fikri, . M. K., Mufid, . A., Purwanto, . A. \& Fahlevi, .M. (2020) Effect of Organizational Citizenship Behavior, Work Satisfaction and Organizational Commitment toward Indonesian School Performance. Systematic Reviews in Pharmacy, 11 (9), 962-971. doi:10.31838/srp.2020.9.140

[159]Nugroho, B. S., Suheri, ., Hakim, . L., Irawan, . B., Sholehuddin, . M. S., Ibrahim, . T., Ridlwan, . M., Hidayati, . L., Aji, . G., Mufid, . A., Ihsan, . N., Purwanto, . A. \& Fahlevi, . M. (2020) Effect of Knowledge Sharing dan Leader member Exchange (LMX) and Organizational Citizenship Behavior (OCB) to Indonesian Lectures' Performance. Systematic Reviews in $\begin{array}{lll}\text { Pharmacy, } & 11 \quad \text { (9), } & \text { 972-981. }\end{array}$ doi:10.31838/srp.2020.9.141
[160]Desky, H., Mukhtasar, ., Istan, . M., Ariesa, . Y., Dewi, . I. B. M., Fahlevi, . M., Abdi, . M. N., Noviantoro, . R. \& Purwanto, . A. (2020) Did Trilogy Leadership Style, Organizational Citizenship Behaviour (OCB) and Organizational Commitment (OCO) Influence Financial Performance? Evidence from Pharmacy Industries. Systematic Reviews in Pharmacy, 11 (10), 297-305. doi:10.31838/srp.2020.10.5095.

[161]Purwanto, H., Fauzi, . M., Wijayanti, . R., Awwaly, . K. U. A., Jayanto, . I., Mahyuddin, ., Purwanto, . A., Fahlevi, . M., Adinugraha, H. H., Syamsudin, . R. A., Pratama, . A., Ariyanto, . N., Sunarsi, . D., Hartuti, . E. T. K. \& Jasmani, . (2020) Developing Model of Halal Food Purchase Intention among Indonesian Non-Muslim Consumers: An Explanatory Sequential Mixed Methods Research. Systematic Reviews in Pharmacy, 11 (10), 396-407. doi:10.31838/srp.2020.10.63

[162]Nugroho, . B. S., Widdah, . M. E., Suryana, . A. T., Ibrahim, . T., Humaira, . M. A., Nasrudin, . M., Mubarok, . M. S., Abadi, . M. T., Adisti, . A. R., Gadzalia, . S. S., Muqtada, . M. R., Purwanto, . A., Fahlevi, . M. \& Sudargini, . Y. (2020) Effect of Leadership Style Toward Indonesian Education Performance in Education 4.0 Era: A Schematic Literature Review. Systematic Reviews in Pharmacy, 11 (10), 371-378. doi:10.31838/srp.2020.10.60

[163]Quddus, A., Nugroho, . B. S., Hakim, . L., Ritaudin, . M. S., Nurhasanah, . E., Suarsa, . A., Karyanto, . U. B., Tanjung, . R., Hendar, ., Pratama, . V. Y., Awali, . H., Mufid, . A., Purwanto, . A., Fahlevi, . M. \& Sudargini, . Y. (2020) Effect of Ecological, Servant dan Digital Leadership Style Influence University Performance? Evidence from Indonesian Universities. Systematic Reviews in Pharmacy, 11 (10), 408-417. doi:10.31838/srp.2020.10.64

[164]Sunarsi, D., Rohaeni, . N., Wulansari, . R., 
Andriani, . J., Muslimat, . A., Rialmi, . Z.,

Kustini, . E., Kristianti, . L. S., Rostikawati, . D., Effendy, . A. A., Purwanto, . A. \&Fahlevi, .M. (2020) Effect of e-Leadership Style, Organizational Commitment and Service Quality towards Indonesian School Performance. Systematic Reviews in Pharmacy, $11 \quad$ (10), 472-481. doi:10.31838/srp.2020.10.71

[165]Heri Erlangga, Wa Ode Sifatu, Dimas Wibisono, Ade Onny Siagian, Rudi Salam, Mahnun Mas'adi, Gunartin, Riri Oktarini, Cornelia Dumarya Manik, Nani, Ahmad Nurhadi, Denok Sunarsi, Agus Purwanto, Gatot Kusjono, (2020), Pharmaceutical Business Competition in Indonesia: A Review, Systematic Reviews in Pharmacy, 11(10):617-623,

https://www.sysrevpharm.org/?mno=3397

[166]Siagian, . A. O., Nufus, . K., Yusuf, . N., Supratikta, . H., Maddinsyah, . A., Muchtar, . A., Sari, . W. I., Sunarsi, . D., Akbar, . I. R., Arianto, . N., Purwanto, . A., Noryani, .\& Wijoyo, . H. (2020) A Systematic Literature Review of Education Financing Model in Indonesian School. Systematic Reviews in Pharmacy, 11 (10), 638-644. doi:10.31838/srp.2020.10.96

[167]Nico Alexander Vizano, Anis Fittria, Mohamad Nuryansah, Muhammad Rikza Muqtada, Gufron , Moh Farhan, Agus Purwanto (2020). HALAL MEDICINE PURCHASE INTENTION AMONG SOUTH EAST ASIAN CONSUMERS. European Journal of Molecular \& Clinical Medicine, 7(7), 58-77.

[168]Edna Maryani,Agus Purwanto,Hayu Kartika ,Moch Haris,Nur Ihsan,Kemas Muhammat Abdul Fatah, Rudy Pramono (2020). DO GEMBA KAIZEN AND 5S REINFORCE MEDICAL EQUIPMENT MANUFACTURING PERFORMANCE ?. European Journal of Molecular \& Clinical Medicine, 7(7), 41-57.
[169]Enji Azizi , Sri Ndaru Arthawati , Sri Hastari , Muhammad Rikza Muqtada , Nur Ihsan Saefulah, Agus Purwanto (2020). IMPACT OF GREEN LEADERSHIP AND ECO EFFICIENCY TOWARD WORK PERFORMANCE : EVIDENCE FROM INDONESIAN PUBLICT HEALTH CENTER. European Journal of Molecular \& Clinical Medicine, 7(7), 28-40.

[170]Akhyar Zuniawan, Sri Mukti Wirawati, Saefulah , Mochammad Fahlevi , Agus Purwanto, Nico Alexander Vizano, Rudy Pramono (2020). Did Seiri Seiton Seiso Seiketsu And Shitsuke Affected Medical Health Industry Business Performance?. European Journal of Molecular \& Clinical Medicine, 7(7), 97-114.

[171]Fatoni , Irawan, Suhroji Adha , Fairus Sintawati, Octoberry Julyanto, Mukhlasin, Ratih Ayu Wulandari, Agus Purwanto (2020). Leadership Style For Indonesian Public Health Center: Charismatic,Bureaucratic,Transactional,

Transformational,Autocratic Or Democratic?. European Journal of Molecular \& Clinical Medicine, 7(7), 115124.

[172]Riza Primahendra Tri Adi Sumbogo Reney Aquino Lensun, Agus Purwanto (2020). Handling Corona Virus Pandemic In The Indonesian Political Context: A Grounded Theory Study. European Journal of Molecular \& Clinical Medicine, 7(8), 113129.

[173]Jannah, M., Fahlevi, . M., Paulina, . J., Nugroho, . B. S., Purwanto, . A., Subarkah, . M. A., Kurniati, . E., Wibowo, . T. S., Kasbuntoro, ., Kalbuana, . N. \& Cahyono, .Y. (2020) Effect of ISO 9001, ISO 45001 and ISO 14000 toward Financial Performance of Indonesian Manufacturing. Systematic Reviews in Pharmacy, 11 (10), 894-902. doi:10.31838/srp.2020.10.134

[174]Nelvitia Purba, Ali Mukti Tanjung, Sri Sulistyawati, Rudy Pramono and Agus 
Purwanto.(2020). Death Penalty and Human

Rights in Indonesia, International Journal of Criminology and Sociology, 9(2020), 13561362, DOI: https://doi.org/10.6000/19294409.2020.09.156

[175]Ade Muslimat, Hariyaty Ab Wahid, Heri Erlangga, Sarwani, Agus Purwanto, Denok Sunarsi. (2020). EFFECT OF ORGANIZATIONAL COMMITMENT ON THE SUSTAINABILITY PERFORMANCE OF INDONESIAN INDUSTRIES.PalArch's Journal of Archaeology of Egypt / Egyptology, 17(6), 8330 - 8347. Retrieved from http://www.palarch.nl/index.php/jae/article/ view/2250

[176]Mukhlis Catio, 2Denok Sunarsi, Munawaroh,Udi Iswadi, Dina Satriani, Achmad Rozi , Agus Purwanto. (2020). Human Resources Management Implementation Impact on Job Satisfaction and Employee Loyalty an Overview.PalArch's Journal of Archaeology of Egypt / Egyptology, 17(6), 8538 - 8547. Retrieved from http://www.palarch.nl/index.php/jae/article/ view/2262

[177]Sudibjo, N., \& Sutarji, T. (2020). The roles of job satisfaction, well-being, and emotional intelligence in enhancing the teachers' em- ployee engagements. Management Science Letters, 10, 24772482.

https://doi.org/10.5267/j.msl.2020.4.002

[178]Sudibjo, N., \& Suwarli, M. B. N. (2020).Job Embeddedness and Job Satisfaction as a Mediator between Work-Life Balance and Intention to Stay. International Journal of Innovation, Creativity and Change, 11(8), 311-331.

[179]Ibrahim, R., Boerhannoeddin, A. and Bakare, K. (2017), "The effect of soft skills and training methodology on employee performance", European Journal of Training and Development, Vol. 41 No. 4, pp. 388-
406.https://doi.org/10.1108/EJTD-08-2016$\underline{0066}$

[180] Albandea, I. and Giret, J. (2018), "The effect of soft skills on French post-secondary graduates' earnings", International Journal of Manpower, Vol. 39 No. 6, pp. 782799.https://doi.org/10.1108/IJM-01-20170014

[181] Viviers, H., Fouché, J. and Reitsma, G. (2016), "Developing soft skills (also known as pervasive skills): Usefulness of an educational game", Meditari Accountancy Research, Vol. 24 No. 3, pp. 368-389. https://doi.org/10.1108/MEDAR-07-20150045

[182]Escrig-Tena, A. B., Segarra-Ciprés, M., García-Juan, B., \& Beltrán-Martín, I. (2018).The impact of hard and soft quality management and proactive behaviour in determining innovation performance. International Journal of Production Economics, 200, 1-14. doi:10.1016/j.ijpe.2018.03.011 